\title{
Urbs in rure: race-grounds, grandstands and the commercialized consumption of urban leisure, 1750-1805
}

\author{
Mike Huggins ${ }^{*}$ \\ c/o The Barn Library, University of Cumbria, 30 Rydal Road, Ambleside, Cumbria, LA22 9BB, UK \\ *Corresponding author. Email: mike.huggins@cumbria.ac.uk
}

\begin{abstract}
This article brings together three aspects of early modern urban life: the later stages of the urban renaissance, the consumer revolution and horse racing. Those towns identified as having an effectively commercialized 'race week' between 1750 and 1805 challenge notions of any trickle-down effect from London. Successful organization and funding came largely from co-operation rather than division between the county aristocracy and gentry and the urban middling sort. Both groups attended, while race weeks were sufficiently popular for many rural and urban workers to sacrifice production time for the allure of their leisure experiences. Racecourse consumer space, with its booths, tents and stands, allowed spectators to enjoy either cross-class mixing or increased social differentiation, the latter most especially on the permanent stone grandstands, an innovation of the period.
\end{abstract}

In 1815, a local engraver advertised four Newcastle-upon-Tyne prints. Alongside two general town views were the town's two most important leisure locations, images worthy of purchase and display for those who consumed leisure's pleasures. One showed the assembly rooms. The other was the grandstand, erected in 1800, a print dedicated to Sir M.W. Ridley (1778-1836), Newcastle's Whig MP, subscriber to the Racing Calendar and racehorse owner. ${ }^{1}$ The imposing grandstand was in a rural location, on the unenclosed Town Moor, close to the Great North Road, bringing together town and country, exploiting fashionable urban building style in a rural context, commercially oriented and reportedly 'commodiously fitted up for the reception of company'.

A contemporary local town booster described it as an 'elegant' stone edifice, of 'very striking appearance'. He drew a direct comparison with country-house architecture, claiming that 'the external aspect of the building is equal to any gentleman's mansion in the neighbourhood'. This parallel was significant. Gentry country houses, as Stobart and Rothery have recently pointed out, were likewise complex material and cultural means of combining conspicuous and everyday

\footnotetext{
${ }^{1}$ Tyne Mercury, 14 Feb. 1815; E. and J. Weatherby, The Racing Calendar (London, 1815).

${ }^{2}$ Newcastle Courant, 31 May 1800.

(C) The Author(s), 2021. Published by Cambridge University Press. This is an Open Access article, distributed under the terms of the Creative Commons Attribution licence (https://creativecommons.org/licenses/by/4.0/), which permits unrestricted re-use, distribution, and reproduction in any medium, provided the original work is properly cited.
} 
consumption, gender identities and sociability. ${ }^{3}$ Like the country house, too, there were views: 'from the galleries on the roof the spectators command a view nearly all round the course'. 4

Civic pride often centred on key buildings modelled on neo-classical urban architecture. ${ }^{5}$ Newcastle's permanent grandstand, built to attract the fashionable and aspiring, thus exemplified its regional identity and status. ${ }^{6}$ Across England, commercial race meetings offered food, drink, gambling facilities, racing and multiple forms of ancillary entertainment during their so-called annual 'race week'. From the 1750s, the building of more permanent grandstands, highly visible forms of consumption, exemplified the new dynamism and confidence of leading provincial racing towns, and elite and middling leisure demand for racing.

Since McKendrick, Brewer and Plumb first presented the provincial English town as the stage for a 'consumer revolution', there has been what White called a 'consumption turn' in eighteenth-century British history. ${ }^{7}$ Most studies have focused more largely on how the varied market in commercial consumer goods met demand, especially luxuries from clothing to lapdogs, using a variety of approaches and standpoints. ${ }^{8}$ Leisure activities have also attracted much attention but the later eighteenthcentury urban race-grounds and their growing numbers of stone-built grandstands have been a largely overlooked feature of this urban leisure market.

Scholars have also shown growing interest in consumption's spaces, sites and places, most especially exploring the complex inter-relationships between leisure, consumption and the social and material spaces in which they took place. ${ }^{9}$ The spatial and social realities of eighteenth-century towns such as York, Bath or Newcastle were shaped by ideas of modernity. Many new buildings expressed neo-Palladian design, social aspiration and spatial exclusivity. ${ }^{10}$ This exploration of towns with race weeks, their semi-rural race-grounds and their buildings, exclusive and less exclusive, addresses these key issues of place, space, leisure consumption and

\footnotetext{
${ }^{3}$ J. Stobart and M. Rothery, Consumption and the Country House (Oxford, 2016).

${ }^{4} \mathrm{~J}$. Baillie, An Impartial History of the Town and County of Newcastle-upon-Tyne (Newcastle, 1801), 167.

${ }^{5}$ See J. Ellis, The Georgian Town 1680-1840 (Basingstoke, 2001).

${ }^{6} \mathrm{H}$. Berry and J. Gregory (eds.), Creating and Consuming Culture in North-East England 1660-1830 (Aldershot, 2004), shows how regionalist identities affected consumption.

${ }^{7}$ N. McKendrick, J. Brewer and J.H. Plumb, The Birth of a Consumer Society: The Commercialization of Eighteenth-Century England (London, 1982); J. White, 'A world of goods? The consumption turn and eighteenth-century British history', Cultural and Social History, 3 (2006), 93-104; see also F. Trentmann (ed.), The Oxford Handbook of the History of Consumption (Oxford, 2012).

${ }^{8}$ Examples include J. Brewer and R. Porter (eds.), Consumption and the World of Goods (London, 1993); E. Edgar and M. Berg (eds.), Luxury in the Eighteenth Century: Debates, Desires and Delectable Goods (New York, 2003); M. Berg, Luxury and Pleasure in Eighteenth-Century Britain (Oxford, 2005); M. Blackwell, The Secret Life of Things: Animals, Objects and It-Narratives in Eighteenth-Century England (Lewisburg, PA, 2007); I. Mitchell, Tradition and Innovation in English Retailing 1700-1850: Narratives of Consumption (Farnham, 2014).

${ }^{9}$ See J. Stobart, 'Shopping streets as social space: leisure, consumerism and improvement in an eighteenth-century county town', Urban History, 25 (1998), 3-21; J. Stobart, A. Hann and V. Morgan, Spaces of Consumption: Leisure and Shopping in the English Town, c. 1680-1830 (London, 2007); E. Welch, 'Sites of consumption in early modern Europe', in Trentmann (ed.), The Oxford Handbook of the History of Consumption, 228-351.

${ }^{10} \mathrm{M}$. Ogborn, Spaces of Modernity: London's Geographies 1680-1780 (New York, 1998); S. Varey, Space and the Eighteenth-Century English Novel (Cambridge, 1990).
} 
commercialization. It provides an overview of racing's growth in popularity over the period from 1750 to 1805 . It analyses urban commercial approaches to generating income to run meetings, identifies more successful racing towns, and explores the complex reasons why they but not similar towns were successful. The second half of the article focuses down on the ways in which the racecourses themselves became more commercialized, and the expansion of course facilities. Permanent stone grandstands, an innovation of the period, signalled a shift towards increased social differentiation, whilst offering a range of pleasures to wealthy occupants, from gambling to seeing and being seen.

Even during the earlier 'urban renaissance', race weeks exemplified wider patterns of consumer demand for and provision of publicly available high-class urban leisure. ${ }^{11}$ Sweet has argued that in many provincial towns a further phase of urban renaissance began from the $1760 \mathrm{~s}^{12}$ Like Borsay she portrayed race meetings, along with inns and alehouses, assembly rooms, theatres, musical entertainments, walks, gardens and promenades and literary experiences, as more or less essential features of urban leisure infrastructure provision and cultural life. In Scotland, these changes came from the 1780s, and racing took off only slowly. ${ }^{13}$ But in England, the post-1750s decades are recognized as a 'key phase' of English horse racing's development, when racing became 'the most rapidly developing and commercially oriented physical recreation'. ${ }^{14}$ By c. 1805 , it had become the first 'proto-modern sport', with a significant measure of economic dependence upon spectators, even if encouraged by the upper classes for their own pleasure and benefit. $^{15}$

\section{The growth of racing $1750-1805$}

In 1761, Goldsmith's novel The Vicar of Wakefield portrayed the 'company' at the races 'all earnestly employed in one pursuit, that of pleasure'. ${ }^{16}$ Such pleasures were consumed as annual calendared 'race weeks', though many only lasted two or three days. Cash and memorandum books and diaries often included their details. ${ }^{17}$ Local race meetings stood out in people's minds, and they were events that people used as key dates in the year, like Christmas, in later conversations. ${ }^{18}$ The races themselves, and the leisure events surrounding them, from the ordinaries, plays, suppers, balls and assemblies to simply watching horses exercise on days before the races, were key consumption experiences. ${ }^{19}$

\footnotetext{
${ }^{11}$ P. Borsay, The English Urban Renaissance: Culture and Society in the Provincial Town 1660-1770 (Oxford, 1989).

${ }^{12}$ R. Sweet, The English Town 1680-1840: Government, Society and Culture (Harlow, 2014), 251.

${ }^{13}$ B. Harris, 'Cultural change in provincial Scottish towns c. 1700-1820', Historical Journal, 54 (2011), $105-41$.

${ }^{14}$ Borsay, Urban Renaissance, 181, 185.

${ }^{15}$ M. Huggins, Horse Racing and British Society in the Long Eighteenth Century (Woodbridge, 2018).

${ }^{16}$ O. Goldsmith, The Vicar of Wakefield (Hannover, 1806), 92.

${ }^{17}$ E.g. The Newcastle Memorandum Book 1771 (Newcastle, 1771); Yorkshire Memorandum Book 1771 (York, 1771).

${ }^{18}$ Many examples can be found in the Old Bailey court verbatim reports, e.g. www.oldbaileyonline.org, $\mathrm{t} 17690405-44$ or t1775108-63.

${ }^{19}$ Huggins, Horse Racing and British Society, 37-78.
} 
Prior to 1740, race meetings had emerged very widely, often very briefly, across England. ${ }^{20}$ By 1736 , it was claimed that 'there is scarce a village so mean that has not a bit of plate raised once a year'. ${ }^{21}$ But following a draconian Act of 1740, each race, with very rare exceptions, had to have prize money of at least $\mathfrak{E} 50$. The Act merged worries about cheating and gambling with social, economic and military concerns, wishing to 'restrain and prevent the excessive increase of horse races' which supposedly encouraged 'idleness', less socially worthy activities and absenteeism from labour, while trying to protect cavalry bloodstock breeding. ${ }^{22}$ There was always opposition to racing from some puritanical commentators, even though the followers of the sport were drawn from all social levels. ${ }^{23}$

The $£ 50$ prize money was hard to raise. Racecourses were usually situated on common land, so no admission could be charged, though some courses did charge carriages. ${ }^{24}$ Numbers of meetings dropped immediately after the Act. Recovery began in the 1750s and numbers rose steadily until the mid-1770s, as towns moved to a more commercial model to attract crowds. Almost half of all towns then had meetings, assuming Corfield's identification of eighteenth-century town numbers is correct. ${ }^{25}$ This was followed by decline: some races became less fashionable as leading owners died, seaside resorts or other courses competed, enclosure closed courses and overseas wars impacted economically. Lambourn, a village in the Berkshire downs, was financially supported by the titled Cravens until enclosure in 1804. Basingstoke's downs were enclosed in 1787. At Stratford-on-Avon, a forced change of date from July to August in 1776 gained less revenue and the land was given over to agriculture. Cirencester had races irregularly until 1794, but then faced intermittent competition from the nearby private Bibury Club meeting. Swaffham had races financially supported by the 3rd earl of Orford until his death in 1791 . The year 1805 provides a useful cut-off point for this study. From then until 1815 onwards, racing's popularity rose, annual numbers of meetings increased and prize money nearly doubled compared to the period from 1793 to 1804 (see Table 1 ). ${ }^{26}$

In 1750, a significant proportion of English races outside Newmarket were for older horses, in heats, often over four miles, though the later century saw greater emphasis on shorter-distance speed and early maturity. In heat races, the winner usually had to win two heats, with rests between. This allowed towns to have only a single race daily, since several horses might each win a heat in turn, enabling a three-day race week to be organized if necessary with just three actual races, though leading meetings had more.

\footnotetext{
${ }^{20}$ Borsay, Urban Renaissance, 355-69, provides a preliminary list.

${ }^{21}$ F. Drake, Eboracum: Or the History and Antiquities of the City of York (London, 1736), 241.

${ }^{22}$ Huggins, Horse Racing and British Society, 140-3.

${ }^{23}$ See R. Malcolmson, Popular Recreations in English Society 1700-1850 (Cambridge, 1973), 51.

${ }^{24}$ By 1778 , Chester charged coaches a shilling: Chester Archives, ZA/B/4/(325), Assembly Book 4, 177778.

${ }^{25}$ P.J. Corfield, The Impact of English Towns 1700-1800 (Oxford, 1982), 8-9.

${ }^{26}$ A. Harvey, The Beginnings of a Commercial Sporting Culture in Britain 1793-1850 (Aldershot, 2004), 8-13.
} 
Table 1. Numbers of English racecourses 1742-1805

\begin{tabular}{cc}
\hline Year & English locations \\
\hline 1742 & 44 \\
1749 & 47 \\
1756 & 78 \\
1763 & 78 \\
1770 & 90 \\
1784 & 91 \\
1791 & 85 \\
1798 & 73 \\
1805 & 65 \\
\hline
\end{tabular}

Source: racing calendars.

\section{The commercialization of racing}

Towns were often well aware that, as in York, the races were 'of great benefit to the city and its citizens', with thousands of pounds spent there during the week. ${ }^{27}$ Race weeks offered advantage and profit, to hotels, inns, taverns, stables and a wide range of luxury service providers. Some townspeople rented out their homes as lodgings to more distant visitors during race week, advertising them in the burgeoning commercial print media, which increasingly engendered consumer interest from a wide community of readers who followed and gambled on the sport. At Nottingham, when there were complaints about the 'badness of the inns and the dirtiness and dearness of the lodgings' in the 1790 s, visits from the country gentry declined. ${ }^{28}$

To be commercially successful long term, a meeting needed enough other urban entertainments to retain visitors, enough racehorse entries to provide entertainment, sufficient income to offer prize money for winning horses and to cover the varied running costs and sufficient interest in racing amongst its elite and public social worlds to make racing too profitable to resist.

To cater for the better-off during race week, ancillary activities were vital. Some towns linked their race week to the assizes, encouraging elite family attendance. Assembly rooms were often central but racing towns might offer ordinaries, balls, the theatre, musical concerts and various sports such as cock-fighting, wrestling or even hunting during the week. In 1770, in County Durham, for example, the middling racecourse at Stockton, supported by the earl of Darlington, advertised 'ordinaries and assemblies as usual', and 'a main of cocks' fought by the 'gentlemen' of the nearby towns of Darlington and Helmsley. ${ }^{29}$

A commercially run meeting had costs: prize money; payments to the clerk of the course, starters, scale operators, various groundsmen, musicians, flag wavers and course-clearers such as 'staff-men'; maintenance bills including painting, joinery and ground-keeping; correspondence charges; and the costs of lengthy advertisements usually in the racing press, in two or three London papers and a couple of regional papers, not just once but for several weeks, to attract entries

\footnotetext{
${ }^{27}$ Drake, Eboracum, 241.

${ }^{28}$ Lincolnshire Archives, 2 PG 12/9/76, letter from steward of races, 1797.

${ }^{29}$ See Newcastle Courant, 5 May, 7 Jul. 1770.
} 
and visitors. ${ }^{30}$ These focused on the races themselves and their conditions of entry, with more minimal details of entertainments and course facilities, suggesting they had become taken-for-granted aspects of the experience.

Prize money was vital to attract racehorse entries. The informal or formal local committees responsible for race-meeting organization, which usually included more prosperous townsmen and county gentry, did this by collecting subscriptions. Many of the 20 members of the newly formed Preston committee in 1791 supported by Lord Derby, for example, were local cotton merchants, manufacturers or in commercial occupations. ${ }^{31}$

Significantly, subscription collectors raised much of the necessary money not from the town but from beyond it. Urban support was often somewhat patchy. Corporation support fluctuated, though any contributions were identified as 'the corporation plate' or the 'city plate'. York, Newcastle and Doncaster provided $\mathfrak{E 5 0}$ plates regularly, some other towns such as Stamford or Scarborough less often and yet others a smaller contribution. While Doncaster provided $£ 50$ in the 1780 s, at Nottingham the corporation gave only $£ 5$. Funding depended on the contemporary complexities of urban leadership and their attitudes to racing.

Local tradesmen, innkeepers, stables, providers of refreshment, entertainment and some luxury-goods sellers expecting to benefit from visitors contributed. Stables only got racehorses if they gave money to the race-fund, innkeepers running lunchtime 'ordinaries' likewise. Innkeepers were major subscribers, identified as such by races described as innkeepers' purses or plates. Anyone wanting a race-ground site had to pay. Surviving subscription lists show much variation, though contributions from the rich and titled county set usually sustained the major meetings. Town contributions by contrast were of smaller amounts and often low: in 1778, at Nottingham just $£ 20$ was collected; at Warwick in 1785 , it was $£ 1717 \mathrm{~s} .{ }^{32}$ At Lichfield, according to the race clerk, there had been no attempt to collect subscriptions amongst the inhabitants between 1769 and 1782, just money collected on the course itself. ${ }^{33}$ Stockport Races, which lasted from 1763 to 1767 , raised more from the townspeople, but in 1763, only 3 subscribers were titled, 28 were Esquires, and nearly 120 were of lower rank, with innkeepers especially prominent. The town lacked race-week entertainments, and by 1767 , of the two days' racing, one had no entries and the other only attracted three horses. ${ }^{34}$

Innkeepers, substantial contributors to gain racecourse booths, sometimes played key organizational roles. In Newcastle, William Loftus played a significant role in commercializing Newcastle's race week after taking over Newcastle's White Hart Inn c. 1767. In 1776, he helped collect subscriptions for Newcastle and Hexham race meetings, and erected an 'elegant temporary stand' for 'the accommodation of the ladies and gentlemen who attend the races' on the Town Moor course. ${ }^{35}$ By

\footnotetext{
${ }^{30}$ For an example of costs, see Doncaster Archives, DD/BW/J/2, stewards' accounts, 1775.

${ }^{31}$ Lancashire Record Office, DDX 103/4, minutes of race proprietors.

${ }^{32}$ Nottinghamshire Archives, DD/E/3/2, Nottingham stewards' accounts, 1778; DD/E/187/16, clerk's accounts for Warwick Races, 1785.

${ }^{33}$ William Salt Library, Lichfield, M1068/3, observations of Mr Hand.

${ }^{34}$ Cheshire Archives, DAR/I/10, Stockport subscription accounts, 1763-66; Leeds Intelligencer, 28 Jul. 1767. See also further account details Alderley and Wilmslow Advertiser, 17 and 27 Feb. 1888.

${ }^{35}$ Newcastle Courant, 11 May 1776; E. Mackenzie, Descriptive and Historical Account of the Town and County of Newcastle, vol. I (Newcastle, 1827), 600.
} 
the later 1790s, he had become treasurer and clerk of the Newcastle course. ${ }^{36} \mathrm{He}$ played a leading role in organizing the building of the new grandstand in 1800, which was largely funded by a share subscription. ${ }^{37}$

Where did extra-urban income come from? It came variously from the crown, the titled and gentry, politicians or sometimes racehorse owners themselves. ${ }^{38}$ At Newmarket, which by 1797 had 46 race days, a winner's prize money came from predominantly aristocratic and gentry owners, in the form of match stakes or sweepstake entries. To a lesser extent, this was also a pattern found at elite courses elsewhere, such as York or Ascot. The small entry fee paid for other races everywhere went to the second-placed horse. Newmarket and some more prestigious courses received money for $£ 100$ Royal Plates, longer-distance races for older horses, funded by royal household expenditure. By the 1750s, there were 15 royal plates contested for across Britain. In the 1770s, they still offered prestige and substantial prize money, although the most attractive sweepstakes races were overtaking them. ${ }^{39}$

The key to long-term race-week success was a town's political, social and cultural connections to the titled and county gentry. Sometimes they exercised territorial influence as principal local landowners. Their regular ritual subscriptions to a range of activities, including donations of race prizes, were obligations that served paternalistically to legitimate their authority and exercise influence. In 1797, for example, the earl of Carlisle gave race prizes to Morpeth and Carlisle, the duke of Bedford to Bedford, Earl Grosvenor to Chester, the duke of Richmond to Lewes and the duke of Devonshire to Derby. ${ }^{40}$

Many further races had prizes described as the members' purse or plate, 'given by' the members of parliament for the borough or county. The popularity of an MP or prospective parliamentary candidates was often judged by their ability to provide donations to activities that benefited a location and its inhabitants, and in some towns gaining local support was particularly important, especially so in freeman-elected boroughs. Of these boroughs, 39 had some racing between 1750 and 1805. Of these, only 7, including Launceston, Berwick and Wells, all distant from London, had less than 10 race weeks. Where the two members were from rival parties, both usually contributed. Occasionally, Tory and Whig rivals for political influence even organized separate race meetings, as at Lichfield between 1748 and 1752, or at Preston between 1786 and $1791{ }^{41}$

\section{Successful racing towns}

Success in raising money enabled a town to sustain meetings over many years. Successful towns can be identified using published data from the annual racing

\footnotetext{
${ }^{36}$ Newcastle Courant, 10 Jun. 1797.

${ }^{37}$ Ibid., 31 May 1800; Mackenzie, Descriptive and Historical Account, 600.

${ }^{38}$ Iris Middleton, 'The developing pattern of horse racing in Yorkshire 1700-1749', De Montfort University Ph.D. thesis, 2000, 45-69; Huggins, Horse Racing and British Society, 175-98.

${ }^{39}$ J. Kay, 'Closing the stable door and the public purse: the rise and fall of the public plates', The Sports Historian, 20 (2000), 18-32.

${ }^{40}$ E. Weatherby, Racing Calendar (London, 1797).

${ }^{41}$ Huggins, Horse Racing and British Society, 137; W. Dobson, History of the Parliamentary Representation of Preston (Preston, 1868), 53.
} 
calendars, supplemented by data from online newspaper files. ${ }^{42}$ Those with more than 10 annual race meetings during that time provide little support for a leisure practice trickling down the urban hierarchy. London itself was not a leading race centre. By contrast, Newmarket was England's leading racing town, the home of the Jockey Club, often with over 40 days of racing during six or seven 'race weeks', but had only 1,793 inhabitants in 1801 . Of the 10 largest towns in terms of population in the 1801 census, exercising a substantial range and depth of economic influence, only Bath, along with Manchester and Liverpool (both northwestern parts of the new urban-industrial world), had significant numbers of meetings. Londoners had to travel to locations such as Epsom or Guildford, and London's small satellite meetings such as Barnet appeared briefly and had little status. At Birmingham, a very few brief minor attempts were made at Coleshill, Solihull and Wednesbury nearby. Bristol, Plymouth and Portsmouth struggled to hold a single recognized race week during this period. Leeds had recognized races only from 1758 into the early 1760s, when Norwich also made a brief attempt.

Racing makes the case for provincial autonomy, rather than any trickle-down effect from London, very strongly. Of the next 11 second-tier towns, Hull, Nottingham, Newcastle, Chester, Leicester and York all regularly sustained successful meetings throughout the period. Some types of town generally failed to develop race weeks. Among resorts, only Scarborough and Bath succeeded. Tonbridge Wells, Harrogate, Buxton, Cheltenham and Malvern had little or no success. Predominantly industrial towns, such as Sheffield, Wolverhampton, Ashtonunder-Lyne or Stoke, also struggled.

So what types of town sustained racing more regularly? Stobart and Schwarz have argued that race meetings were one of the factors of luxury provision characterizing what they called 'residential leisure towns', using a simple measure of at least a single race meeting in the period around $1790 .{ }^{43}$ These 53 'residential leisure towns' all provided a wide range of cultural amenities and services, and their economies relied in part on revenue from visitors. ${ }^{44}$ Of those leisure towns, 37 successfully sustained at least 10 annual meetings over the period and many far more. Of the 16 others, most were ports, with sea and dockyard focus. Boston, Dover, King's Lynn, Rochester and Yarmouth never had calendared meetings of any status, and Southampton only briefly in the 1770 s and then from $1801 .^{45}$

\footnotetext{
${ }^{42}$ Annual racing calendars were J. Cheny, Historical List of Horse-Matches Run (1728-50); J. Pond, Sporting Kalendar (1751-57); R. Heber, Sporting Kalendar (1751-68); W. Tuting and T. Fawconer, Sporting Calendar (1769-72); J. Weatherby, Racing Calendar (1773-93); E. Weatherby, Racing Calendar (1794-1805).

${ }^{43}$ J. Stobart and L. Schwarz, 'Leisure, luxury and urban specialization in the eighteenth century', Urban History, 35 (2008), 216-36.

${ }^{44}$ Bath, Berwick, Beverley, Birmingham, Boston, Bristol, Bury St Edmunds, Cambridge, Canterbury, Chester, Chichester, Colchester, Coventry, Derby, Doncaster, Dover, Durham, Exeter, Gloucester, Hereford, Hull, Ipswich, Lancaster, Leeds, Leicester, Lewes, Lincoln, Liverpool, Lynn, Manchester, Monmouth, Newark, Newcastle, Northampton, Norwich, Oxford, Peterborough, Plymouth, Portsmouth, Preston, Reading, Rochester, Salisbury, Shrewsbury, Southampton, Stafford, Stamford, Wakefield, Winchester, Windsor, Worcester, Yarmouth, York.

${ }^{45}$ Berwick, Norwich, Coventry, Chichester, Gloucester, Leeds and Monmouth also only held races occasionally.
} 
Very successful towns had race weeks for at least 45 of the 56 years. There were three high-status locations: Newmarket, used since the Stuart period; Ascot (population less than 500) near the royal palace at Windsor; and Epsom (population 2,286), a former spa town close to London. Burford in Oxfordshire (population $1,725)$, on major coaching routes east-west and north-south, was initially fashionable until decline and closure in 1802 .

Almost all the rest were formal 'shire' or 'county' towns. Of the 39 traditional English county towns, 22 had regular race weeks, while Chelmsford fell only just below 80 per cent, taking off from 1761, and Stafford likewise came close. There were 9 further successful towns that functioned as secondary county centres, with quarter-sessions, diocesan or other administrative functions: Chesterfield, Stamford, Lichfield, Salisbury, Wakefield, Beverley, Richmond, Malton and Doncaster. Most of these towns were parliamentary boroughs. Plotting these towns onto eighteenth-century toll roads also shows them all well sited on key routes, with several on the Great North Road, so easy of access by coach, as were the two further towns which sustained racing regularly from 1750 to 1805 , Grantham and Morpeth.

Some county towns lacked success. Cambridge, close to Newmarket, had no races. Oakham, in Rutland, was too small. Aylesbury sustained meetings only until 1782. Hertford had calendared races after 1800. County towns more distant from the capital struggled hardest to generate interest, though Carlisle, Newcastle and Durham bucked the trend. Towards the south-west of England, Wilton and Trowbridge in Wiltshire were overshadowed by Salisbury, Exeter and Gloucester had erratic success, Monmouth tried meetings in the 1770s, Dorchester occasionally from the 1780s, and Taunton after the 1790s. In eastern England, Oakham and Norwich never succeeded. In the north-west, Lancaster only took off from the 1760s, about the same time as its local rival Preston. In Westmorland, Appleby had races in the 1790s. A few further towns sustained racing at a reasonably high level in 30 to 40 years between 1750 and 1805. Most were boroughs, the others mainly market towns. ${ }^{46}$

\section{Consuming racing: on the course}

From the 1750s onwards, urban workers worked longer and sacrificed holidays and leisure time to purchase more consumer goods, though the parallel substantial increase in work requirements for agricultural workers showed little change in consumption patterns. ${ }^{47}$ Yet for the annual race week, many sacrificed production time for the allure of its leisure experiences. Agricultural workers perhaps only visited their local races for a day. Some amongst the middling group might go to several race meetings. On race days, the 'county-' and country-folk came town-wards

\footnotetext{
${ }^{46}$ Boroughs included Abingdon, Preston, Morpeth, Bridgenorth, Ludlow, Whitchurch, Northallerton, Scarborough and Richmond. Maidenhead, Knutsford, Nantwich, Blandford, Stockton, Preston, Swaffham and Hexham were market towns.

${ }^{47}$ H.-J. Voth, Time and Work in England 1750-1830 (Oxford, 2001); J. de Vries, The Industrious Revolution: Consumer Behaviour and the Household Economy, 1650 to the Present (Cambridge, 2008); R.C. Allen and J.L. Wiesdorf, "Was there an "industrious revolution" before the industrial revolution? An empirical exercise for England, c. 1300-1830', Economic History Review, 64 (2011), 715-29.
} 
and the towns-folk went to the country, since race-grounds were usually well outside the town: Whittington Heath was three miles from Lichfield; Barnham Down over seven miles from Canterbury. Courses filled with people, horses and horsedrawn vehicles. This created a carnival atmosphere, and much social mixing, not to everyone's approval. At York, where 'there was great resort of people from all parts', Drake reported that the races were a 'barbarous diversion', but ones which 'draw in the country people in vast crowds...the gentry, nay even the clergy and prime nobility are mixed amongst them...the noble peer is dressed like his groom'. At Ascot in 1797, there was a 'heterogeneous assemblage' where 'princes, peers and gentlemen' were seen in association with 'prostitutes, pickpockets and blackguards'. 48 One 1804 novel noted women's presence in 'a mixed assemblage' that included 'noblemen and thieves, gentlemen of fortune and beggars, peeresses, women more modest... and kept mistresses' ${ }^{49}$ Carriages, phaetons, curricles and carts dotted the course, 324 carriages at York in 1766 but only 184 the following year. ${ }^{50}$ Newspapers described courses 'crowded' or with a 'numerous' attendance. At Oxford Races in 1770, a figure of 7,000 was quoted. ${ }^{51}$ An 1804 match at York, on the last day of York Races to settle a very substantial wager, with one rider a young woman, attracted thousands from every part of the surrounding country, with contemporary estimates of 'nearly 100,000 at least'. ${ }^{52}$

As contemporary prints and paintings show, race-grounds also held a number of temporary and permanent buildings. ${ }^{53}$ Nearly all courses encouraged the erection of temporary marquees, booths, tents and huts, commercial enterprises only allowed to those who had contributed to the subscription. The best sites went to those who had paid most. Locals were prioritized. Buildings were erected before the races, and normally had to be quickly taken down and the ground made good afterwards. They offered shelter, sold drink, foodstuffs, gambling opportunities and sometimes sex. Pedlars, basket-people and others also circulated.

By the early 1700s, race-week organizers recognized the commercial possibilities of revenue from temporary wooden viewing platforms for those who could afford them. These were variously called 'stands', 'standings' or 'scaffolds', usually built about a fortnight before the races, as at Ascot. ${ }^{54}$ This clearly reflected a demand, people willing to spend to gain better viewpoints. An Ascot watercolour (c. 1765) shows a wooden viewing platform at first-floor level, partly open to the elements, containing several rows of benches, with a sloping roof. ${ }^{55}$ Such stands were practical, utilitarian and provided revenue to their builders. Tickets could sometimes be purchased from select coffee houses and inns beforehand.

Some were quite large. At Basingstoke in 1773, Robert Cane paid two guineas annually to the race-fund for 21 years for a stand no more than 200 feet long

\footnotetext{
${ }^{48}$ Ascot Chronicle, 26 Jun. 1797.

${ }^{49} \mathrm{H}$. Whitfield, A Picture of Life, vol. II (London, 1804), 42.

${ }^{50}$ St James Chronicle, 3 Sept. 1767.

${ }^{51}$ Oxford Journal, 4 Aug. 1770

${ }^{52}$ York Herald, 25 Aug., 1 Sept. 1804.

${ }^{53}$ Examples include William Mason, A Country Racecourse (1786); John Nixon, Brighton Races (1805); Thomas Rowlandson, Racing (1811).

${ }^{54}$ D. Laird, Royal Ascot (London, 1976), 25.

${ }^{55}$ P. Sandby, Ascot Heath Races (1765).
} 
and 30 feet wide. ${ }^{56}$ A shilling became a common entrance charge. At select Bath, a local shopkeeper built what Pierce Egan later called a 'mean and contemptable' stand, selling numbered tickets at $2 s 6 d$ for its supposed 'fine prospect'. 57 Prices rose as better wooden stands were constructed, often with drinking places below, viewing space above, fully roofed and some even with sash windows. Some racecourses introduced a separate 'Ladies' Stand', with better facilities. Manchester Ladies' Stand on Kersal Moor had 'conveniences' in it in 1804, like the drinking booths. ${ }^{58}$ Preston race committee annually inspected stands to see that they were substantial, safe and in good condition. ${ }^{59}$ Some others were less careful, and there were grandstand collapses at a number of courses. ${ }^{60}$ Their pricing made them accessible to a relatively heterogeneous clientele, and they were not of high status.

\section{Permanent grandstands}

From the 1750s onwards, just as the urban renaissance had involved extensive remodelling of the townscape along classically inspired lines, urban ambition and status began to be demonstrated through a more permanent racecourse feature, a stone or brick grandstand for the better-off, which likewise often drew on fashionable neo-classical architectural style.

Elite courses like Newmarket, Ascot or Goodwood initially tried to avoid having these public grandstands to retain their social exclusivity, keeping to private permanent stands for royals and the ruling elite. At Newmarket, the King's Stand, predating 1669, was a brick-built square tower overlooking the finishing post. ${ }^{61}$ In $c$. 1760, a stand was built for the duke of Cumberland on similar lines. The duke of Portland's brick stand in 1774 added a flat-roof viewing platform. ${ }^{62}$ Goodwood got its first grandstand as late as 1904 .

Elsewhere, there were small wooden judges' boxes, distance stands or stewards' stands for the elite, and these began slowly to be replaced in stone as their commercial income potential was realized. By 1761 at Chester, its corporation committee thought its stands of timber, brick or other materials at the starting and distance place could be made larger to contain 40 or 50 persons and that profit might be made by hiring places out on race days. ${ }^{63}$

From the mid-eighteenth century onwards, successful racing towns began to recognize growing demand for more permanent stone-built grandstands to provide more social differentiation for the better-off. In terms of the so-called 'consumer

\footnotetext{
${ }^{56}$ Hampshire County Archives, 148m71/4/7/10, indenture.

${ }^{57}$ Bath Chronicle, 6 Sep. 1770; P. Egan, Walks through Bath: Describing Every Thing Worthy of Interest (Bath, 1819), 211.

${ }^{58}$ Manchester Mercury, 17 Apr. 1804.

${ }^{59}$ Lancashire Record Office, DDX103/4, minutes of Preston Races, 14 Dec. 1810.

${ }^{60}$ Bath Chronicle, 3 Oct. 1793; Mackenzie, Descriptive and Historical Account, 599-600.

${ }^{61}$ D. Oldrey, T. Cox and R. Nash, The Heath and the Horse: A History of Racing and Art on Newmarket Heath (London, 2016), 174 and fig. 21.

${ }^{62}$ The University of Nottingham, Manuscripts and Special Collections, Pw F 5880, letter from John Johnson, Berners Street, London, to W.H.C. Cavendish-Bentinck, 3rd duke of Portland, Burlington House, London, 16 Apr. 1774.

${ }^{63}$ Cheshire Archives, ZA/B/4/201v, Assembly Book 4.
} 
revolution', these represented a novel shift in production, a more specific symbol of modernity, with new levels of comfort. They were a cultural refashioning of the simpler scaffolds, with more high-cost entrance fees demanding more conspicuous spending. The move to the building of stone or brick grandstands, variously described as 'race stands', 'stands', 'grandstands', 'stand houses' or 'standing houses', conveyed an image of permanency to a town's racecourse, added to its sporting status and attracted wealthy custom. They merged several key features of urban culture for towns enjoying a later urban renaissance: the pursuit of status, civility and sociability, and cultural differentiation.

The race-ground itself had encouraged social mixing across classes. By contrast, these grandstands encouraged the pursuit of status and cultural differentiation. By allowing access only to those able to afford it, the stand architecture imposed a larger physical demarcation between them and other attenders. Grandstands offered spaces where members of the rising middling rank could mingle with their superiors, an alternative social area for some who had previously watched from carriages or on horseback.

For towns, they became another form of architectural civic display and urban status, a reminder of wealth and social power. According to a 1797 gazetteer, Nottingham's stand was 'doubtless one of the finest buildings of the sort in the kingdom'. ${ }^{64}$ Doncaster's course supposedly stood 'unrivalled', and 'the grandstand, for its elegance and accommodation [was] not excelled by any in the kingdom'. 65

Ellis has argued that the built environment of a town and the ways it wished to portray itself were influenced by ideas from London. ${ }^{66}$ This was not especially so for race-ground development, which spread outwards from Yorkshire, where the first innovating moves to erect commercially focused permanent stone or brick grandstands took place. Architectural historians have suggested that York racecourse had the first permanent public grandstand. ${ }^{67}$ In fact, an earlier Yorkshire example was built at Wakefield racecourse in 1747 by the young architect John Carr (1723-1807). It was an elegant neo-classical design, with an imposing first floor, and a novel roof viewing platform. ${ }^{68}$ In 1753, the politician, Yorkshire magnate and racehorse owner the 2nd Marquis Lord Rockingham proposed the building of a grandstand at York's Knavesmire racecourse, further encouraging the city's civility, sociability and improvement. Carr's design, seven bays across, in Italian Palladian style, was chosen above that of three other architects. Rockingham saw the work as sufficiently important to preserve a plan and detailed account book. ${ }^{69}$ Over the next few decades, many subsequent permanent stands derived their form and role from that at York.

Costs ensured that initial take-off was slow, however. Regional rivalry and identity encouraged two small public stands in Cambridgeshire for Peterborough Races (at Wothorpe) and Stamford in 1763. Beverley, the leading town in Yorkshire's East

\footnotetext{
${ }^{64} \mathrm{R}$. Thoroton, Thoroton's History of Nottinghamshire, vol. II (London, 1797), 68, 161.

${ }^{65} \mathrm{~W}$. White, History, Gazetteer, and Directory of the West-Riding of Yorkshire, vol. I (Sheffield, 1837), 227.

${ }^{66}$ Ellis, The Georgian Town.

${ }^{67}$ P. Roberts and I. Taylor, Racecourse Architecture (London, 2013).

${ }^{68}$ P.L. Dawson, Secret Wakefield (Stroud, 2015), n.p.

${ }^{69}$ Sheffield Archives, WWM/A/1395, grandstand account book, and VWM/Maps/154 plan. For broader context, see P. Borsay, 'The cultural re-fashioning of eighteenth-century York', in M. Hallett and J. Rendall, Eighteenth-Century York: Culture, Space and Society (York, 2003).
} 
Riding, erected a larger stand in 1767, and Chester one in 1769. Stands were built at Lichfield and Lewes in 1772-73. In Yorkshire's North Riding, Richmond's stand, begun in 1775, planned by Carr, was built after it gained a Royal Plate and extended its small but ambitious social season. ${ }^{70}$ Stamford erected a larger stand in 1776 . Doncaster (1776) and Nottingham (1777) sought status with Carr-planned stands. Manchester built a subscription stand in 1777. Only a few further stands were built before a further burst of building occurred, including second stands, from 1800 onwards, at courses such as Blandford, Doncaster, Durham, Chester, Lancaster, Lichfield, Lewes, Malton, Newcastle, Salisbury, Walsall and Warwick.

The various architectural designs varied somewhat but usually shared characteristics. Almost all were of stone, of ashlar or rusticated masonry, although a few were of brick, generally founded on classical proportions, using orders and symmetry, arches, arcades and columns, and with modern sash windows. Ground floors variously had storage rooms, offices, entertainment/meeting rooms, kitchens, rooms for drinks and basic water closets. An internal staircase normally rose to one or two principal reception rooms on the first floor lit by glazed windows with fireplaces to provide heat on cold days. Ornamental balustrades or railed viewing balconies gave outside access. Carr's drawings usually incorporated a 'miranda' of about three steps which aided viewing and socialization. ${ }^{71}$ Some had balustraded or railed viewing roofs, flat or with a gently sloping gradient. Later, tiered standing or even seating was sometimes introduced. Many stands were physically enclosed by a stone wall, fence or railings. The size of grandstands varied considerably. York's grandstand was 200 feet long, Chester's 90 feet and Lichfield only 40 feet. Many used land leased from local aristocrats on favourable terms, as at Lichfield, where Lord Paget, wanting to encourage a stand, asked a minimal rent. ${ }^{72}$ Contemporary estimates of building costs varied, from $£ 700$ to more commonly $£ 1,500$ or more. York's total expenditure was $£ 1,896{ }^{73}$ Nottingham's grandstand cost $£ 1,702 .{ }^{74}$

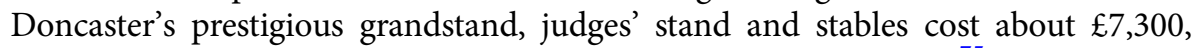
helping it overtake York as an aristocratic horse-racing attraction. ${ }^{75}$

Like assembly rooms, and the race meetings themselves, funding came from subscription shares. These included tokens for long-term (and transferrable) stand admission, usually costing around 5 guineas each. At York, where shares gave free admission for a hundred years, some titled subscribers bought up to four shares, but single shares were bought by small gentry and successful York tradesmen. By 1776, Nottingham subscribers were expected to pay 'at least' 20 guineas but got two silver tickets to the stand and assembly rooms. Five titled individuals subscribed $£ 200$ each and a further five $£ 100$ each. Its other subscribers were a mixture of county landowners and middling groups, including clerics, a doctor, bankers, merchants, tradesmen and some aldermen. ${ }^{76}$

\footnotetext{
${ }^{70}$ Newcastle Chronicle, 9 Mar. 1776.

${ }^{71}$ T. Gibson, 'The designs for the Knavesmire grandstand, York', Georgian Group Journal, 8 (1998), 83.

${ }^{72}$ W. Pitt, A Topographical History of Staffordshire (Newcastle-under-Lyme, 1817), 99.

${ }^{73}$ Sheffield Archives, WWM/A/1395, account book for York grandstand.

${ }^{74}$ J. Orange, History and Antiquities of Nottingham, vol. II (Nottingham, 1840), 940.

${ }^{75}$ J. Tomlinson, Doncaster from the Roman Occupation to the Present Time (Doncaster, 1887), 206.

${ }^{76}$ Orange, History and Antiquities of Nottingham, 940-1. Nottingham Archives, DD/E/3/3-4, n.d. \& 1776: DD/E/3/5-6, 11 Aug. 1780 \& 9 Aug. 1781. Minutes of meetings of subscribers.
} 
Most high-status grandstands could accommodate between 500 and 1,000 people. The first permanent public stand at Ascot, built c. 1793, accommodated 650 attendees. ${ }^{77}$ Actual attendance figures are lacking, since subscribers could use the stand freely, and there were always some complimentary tickets. Others purchased a grandstand ticket costing either a guinea or half a guinea for race week. At Lichfield between 1784 and 1786 a mean of 79 three-day stand tickets were sold yearly at $10 s 6 d$, and 86 one-day tickets at $5 s .{ }^{78}$ At some courses, revenue could be supplemented outside race week by letting the stand for other events such as military parades, cricket or boxing matches. ${ }^{79}$

In recent years, there has been growing interest in connections between studies of consumerism and studies of space and material culture, exploring the uses made of products and the practices formed round them. ${ }^{80}$ Grandstands were complex, socio-cultural luxury spaces that allowed for a wide variety of choices and experiences, though these can only be touched on briefly here. In part, they substituted observation of the races themselves for the eating and drinking, gambling and more sexualized carnival racecourse life. Their multiple meanings could be ambivalent and changeable, variously linked to images of the rural, to gender roles, to the importance of gambling and politics, to love of the horse, to commercialization, to social display and to commodification. Some came to the races because they loved horses; some because they loved to bet; some for political or for commercial reasons; some for the spectacle and others to see and be seen.

Race meetings always brought together sport, spectatorship and spectacle. ${ }^{81}$ Grandstand spectators were separated from the rest of the crowd, literally and metaphorically looking down on everyone else, demonstrating visibly their presence and superiority, reinforcing social distinctions and producing and consuming the raceweek spectacle. Those below them, occupying a lower position in society, literally looked up to them. Newspaper reports used the language of spectacle even for clothing, telling readers about the 'promenade of fashion' on 'display'.

Like pleasure gardens, racecourses offered a carefully modified 'natural' environment, less-polluted fresh air and a more attractively beneficial contact with nature in an apparently 'natural' landscape, another example of the urban-rural interface and use of towns' 'green spaces'. ${ }^{82}$ The grandstands, tents, huts and booths were all

\footnotetext{
${ }^{77}$ Morning Post, 28 May 1824; R. Cruikshank, 'The king at Ascot Races', in The Spirit of the Public Journals for the Year M.DCCC.XXIII, vol. III (London, 1826), 464.

${ }^{78}$ A.J. Kettle, 'Lichfield Races', Staffordshire Archaeological and Historical Society, 6 (1964), 39-44; Staffordshire Record Office, D.593/F/3/12/4/3, stand receipts.

${ }^{79}$ D. Brailsford, 'Sporting days in eighteenth-century England', Journal of Sport History, 9 (1982), 43.

${ }^{80}$ E.g. J. Stobart, Sugar and Spice: Grocers and Groceries in Provincial England 1650-1830 (Oxford, 2012), 242, 253.

${ }^{81} \mathrm{~N}$. Zatec, 'Spectacle and spectatorship at the nineteenth-century American racetrack', European Journal of American Studies, 14 (2019), http://journals.openedition.org/ejas/15371.

${ }^{82} \mathrm{P}$. Borsay, 'Town or country? British spas and the urban-rural interface of tourist history', Journal of Tourism History, 4 (2012), 155-69; P. Borsay, 'Nature, the past and the English town: a counter-cultural history', Urban History, 44 (2017), 27-43; V. Scribner, 'Cultivating "cities in the wilderness": New York City's commercial pleasure gardens and the British American pursuit of rural urbanism', Urban History, 45 (2018), 275-305; P.J. Corfield, Vauxhall and the Invention of Urban Pleasure Gardens (London, 2008); P. Clark (ed.), The European City and Green Space: London, Stockholm, Helsinki and St. Petersburg, 1850-2000 (Aldershot, 2006).
} 
commodified: privately run, potentially profitable venues on an urban model that channelled the inherently rural nature of their surroundings.

Some people were there for political reasons. As Cox has recently re-emphasized, horse racing was an essential part of the political structure at local, national and regional levels. ${ }^{83}$ Many grandstand shares were bought by leading county and urban purchasers, so at locations such as York research has shown they offered a key site of assembly for political discourse: opportunities in the ever-changing dynamics of patronage exercise, seeking of preference or position, the shifting of political interests and the exercise of political corruption. ${ }^{84}$ Whig Edmund Burke went to Aylesbury Races because 'the pulse of the county could be found there'. ${ }^{85}$ Attenders passed on political information gathered. ${ }^{86}$

Many attenders were landed gentry and the urban middling groups, couples and groups of friends, able to display and perform their 'polite' status. They could mix and converse freely, hone their social skills, foster kinship, political and business bonds and engage in intensive levels of sociability. Contemporary diaries and letters often boasted of being there. The lawyer and militia officer John Courtney of Beverley's diary proudly mentioned his three days on a temporary stand at the races but he was still prouder when he got a silver ticket for the new permanent stand in 1767, one of 330 tickets issued. ${ }^{87}$

Cultural and social differentiation did not always succeed. Allowing entrance to those who could pay opened up the stand to working-class 'blacklegs', racecourse gamblers with carefully practised external appearances, aping civility and politeness. And pickpockets with gentlemanly appearance could purchase a stand ticket and then exploit the distraction of the race. Even Lord Rockingham once was relieved of a gold snuffbox in the grandstand at York. ${ }^{88}$

Women's urban leisure life has often been treated as peripheral, with a strong historiographical emphasis on male leisure life. ${ }^{89}$ But although consumption was shaped and mediated by gender relationships, it is clear that women were very active consuming agents on the racecourse. In assemblies, pleasure gardens and racecourses, men increasingly appeared with women, and both had their appearance and behaviour assessed. ${ }^{90}$ Appearance mattered, and at least one London hairdresser advertised 'the nobility and gentry' of his availability at Oxford and Abingdon race meetings. ${ }^{91}$ As more elite women attended meetings, first in carriages and then on the stands, they were joined by larger numbers of middling

\footnotetext{
${ }^{83} \mathrm{O}$. Cox, “Newmarket, that infamous seminary of iniquity and ill manners": horses and courts in the early years of George III's reign', The Court Historian, 24 (2019), 269-81.

${ }^{84}$ J.A. Phillips, Electoral Politics in Unreformed England: Plumpers, Splitters and Straights (Princeton, 1982); C.B. Cone, 'Parliamenteering and racing', History, 17 (1975), 407-20; Huggins, Horse Racing and British Society, 122-53.

${ }^{85} \mathrm{C}$. Fitzwilliam and R. Bourke (eds.), Correspondence of the Right Honourable Edmund Burke, vol. I (London, 1844), 472.

${ }^{86}$ Nottingham Archives, DD/FJ/11/1/7/108, Sir George Saville to Foljambe of Osberton, 31 Aug. 1779.

${ }^{87}$ Hull University Library, DDX/60/2, Courtney diary, 44.

${ }^{88}$ Northampton Mercury, 2 Sep. 1776.

${ }^{89}$ R. Sweet and P. Lane, Women and Urban Life in Eighteenth-Century England (Farnham, 2003), 1.

${ }^{90} \mathrm{P}$. Carter, Men and the Emergence of Polite Society 1660-1800 (London, 2001), 53-75.

${ }^{91}$ Oxford Journal, 5 Aug. 1775.
} 
women, a pattern of emulation found also in contemporary shopping. ${ }^{92}$ By 1777 , even Newport Pagnell had 'booths and stands over them for ladies and gentlemen to see the races'. 93 The many prizes advertised as a 'Ladies' Purse' or 'Ladies' Plate' during the period were recognitions of the importance of their presence. Women's letters back to friends and relatives about their visits were full of accounts of raceweek experiences: the balls and assemblies, political and social gossip and the races themselves. ${ }^{94}$ The more exclusive stone-built grandstands attracted elite women, and at Stamford in 1770 a letter noted that 'there were supposed to be 150 ladies or more on the stand'. 95

Many stand attenders enjoyed wagering, since eighteenth-century gaming and wagering were ubiquitous. ${ }^{96}$ Wagering on fighting cocks, pugilists, cricket or horses, along with associativity, created the climate for sports to flourish. ${ }^{97}$ Racecourse betting was powerfully driven by press publicity, which advertised meetings, provided betting information and quoted odds. Initially, the betting market operated on the course itself, often centred round a 'betting post', but grandstands provided a better, more sheltered and sociable place to wager. This quickly became another function of many stands. By 1807, press reports even sometimes gave details of shifting odds in the stand during the race. ${ }^{98}$ From the 1780 s, some stands were being described as 'betting stands'. 99

The more gentlemanly face of betting was associated with key elite characteristics (politeness, honour, status and the ability to meet one's debts). Too-great wagering was seen by some as 'against good manners', an offence against civility. ${ }^{100}$ For a minority, conspicuous consumption led to extravagant and reckless wagering, and substantial losses. One young man took $£ 700$ to Doncaster Races in 1770 and came home with 15 shillings. ${ }^{101}$ Lord Grosvenor reportedly lost $£ 200,000$ on the turf. The emotions associated with wagering attracted a range of potential problems of stand behaviour, often linked to wagering debts. In 1796 in the betting stand at Ascot, a warning not to bet with a Kingston brewer, who, it was said, 'neither paid what he lost nor he borrowed' led to a later duel, and in a dispute over a supposed previous unpaid racing debt in York's grandstand a wealthy Yorkshire landowner was assaulted and whipped. ${ }^{102}$

\footnotetext{
${ }^{92}$ E. Kowaleski-Wallace, Consuming Subjects: Women, Shopping, and Business in the Eighteenth Century (New York, 1997).

${ }^{93}$ Northampton Mercury, 20 Jun. 1777.

${ }^{94}$ E.g. Hampshire Archives, $1 \mathrm{M} 44 / 71 / 28$, letter of 7 th countess of Banbury to her son on events of race week, 13 Jul. 1785; 1M44/75/24, letter to Lord Wallingford re Winchester race-week events.

${ }^{95}$ Northampton Mercury, 11 Jun. 1770.

${ }^{96}$ P.D. Deutsch, 'Fortune and chance: aristocratic gaming and English society, 1760-1837', New York University Ph.D. thesis, 1991; J. Richard, 'Arts of play: the gambling culture of eighteenth-century Britain', Princeton University Ph.D. thesis, 2002.

${ }^{97}$ M. Huggins, 'Associativity, gambling and the rise of proto-modern sport', Journal of Sport History, 47 (2020), 1-17.

${ }^{98}$ E.g. York Herald, 5 Sep. 1807.

${ }^{99}$ An early example was shown in William Mason's A Country Racecourse, painted in 1786.

${ }^{100} \mathrm{~K}$. Thomas, In Pursuit of Civility: Manners and Civilisation in Early Modern England (New Haven, CT, 2018), 60.

${ }^{101}$ Leeds Intelligencer, 16 Oct. 1770.

${ }^{102}$ The Monthly Magazine, 34, Nov. 1813, 363-5; Newcastle Courant, 31 Aug. 1805.
} 


\section{Conclusion}

After English horse-racing's brief hiatus in the 1740s, it became more commercialized, becoming an important part of urban leisure consumption in the next decades as numbers of urban meetings rose. Even so, race weeks were by no means a universal urban function. Some of the largest towns in England, including London, did not sustain them. Between 1750 and 1805, those towns where race weeks flourished most successfully were largely county towns, towns with similar administrative functions which brought together justices and gentry, and 'leisure towns', although not all of such types succeeded. Spa towns and resort towns, with a few exceptions such as Bath, struggled, as did most port towns and industrial towns.

Racecourses provided very active contexts for eighteenth-century society. They offered different uses of space, shaping and being shaped by social relationships. So while the course itself offered strong elements of cross-class social mixing, the booths and temporary stands offered either social mixing or some social differentiation, and permanent grandstands more social differentiation. This encouraged middling and elite women to attend race meetings. While there was little evidence of social emulation in terms of basic attendance, with townspeople, country-folk and landed groups all attending from early in the century, grandstands encouraged those of middling groups who sought status and networking opportunities.

Race weeks encouraged the social and political networks of urban and rural life. In racing there was no rural-urban divide of the sort described by Estabrook. ${ }^{103}$ Urban-rural links were regular, clear and complementary. While many studies have identified the middling sort as the leading actors in later eighteenth-century leisure consumption, this was less so in racing, where race-week organization and grandstand building represent rather a collaborative enterprise by a crosssection of the urban middling classes and the landed county gentry, with both groups contributing to organization, funding and attendance. Much of the funding for races at successful towns came not from the townspeople themselves but variously from the crown, the titled and gentry, politicians or sometimes racehorse owners themselves. Corporations sometimes contributed, and local innkeepers and stablemen donated in hopes of commercial benefit. Other townspeople also contributed, but their share could be as low as 10 per cent or less of the fund.

Finally, the races illustrate the connections between studies of consumption and studies of material culture, especially so in the variety of uses made of grandstands, not just for spectating and enjoying the spectacle, but also for socialization, gambling and political activities, in a context of pleasure, sociability and politeness, although with occasional disputes driven by wagering issues.

\footnotetext{
${ }^{103}$ C. Estabrook, Urbane and Rustic England: Cultural Ties and Social Spheres in the Provinces 1660-1780 (Manchester, 1998).
}

Cite this article: Huggins M (2022). Urbs in rure: race-grounds, grandstands and the commercialized consumption of urban leisure, 1750-1805. Urban History 49, 44-60. https://doi.org/10.1017/ S0963926820001017 